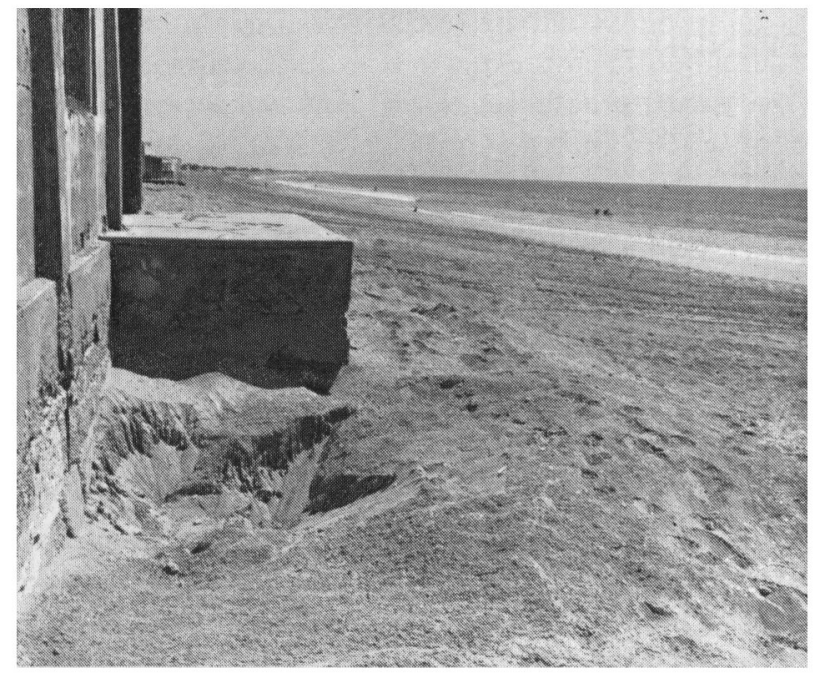

FIG. 1. A line of beach cottages encroaches on the turtle nestingbeaches of Sandspit and Hawkes Bay, near Karachi, Pakistan, and forms a barrier to nesting turtles. In the foreground is a collapsed turtle-nest and in the background can be seen many turtle-tracks. Photo: Rodney V. Salm.

hours on a full-moon night the turtles were beginning to come ashore. By 2100 hours several were nesting, and by 2200 hours things were chaotic. It was a remarkable experience: one could choose any area where nesting activity was high and, without having to move, watch various stages of emergence, nest-digging and -filling, and egg-laying-all simultaneously in progress.

At present these turtles are safe from harvest, but the problem in Pakistan goes beyond controlling harvest; the nesting beaches are themselves threatened. At Sandspit and Hawkes Bay beach, cottages have been built in a continuous string along the crest of the primary dune ridge and encroach on the nesting area (Fig. 1). Several cottages are derelict, and the construction rubble further diminishes and destroys the ground available for nesting (Fig. 2). The cottages have the effect of channelling turtles to the interspaces, which increases the risk of egg clutches of other turtles being unearthed.

Expert opinion was requested by the Seychelles Government; its failure to materialize has jeopardized continued

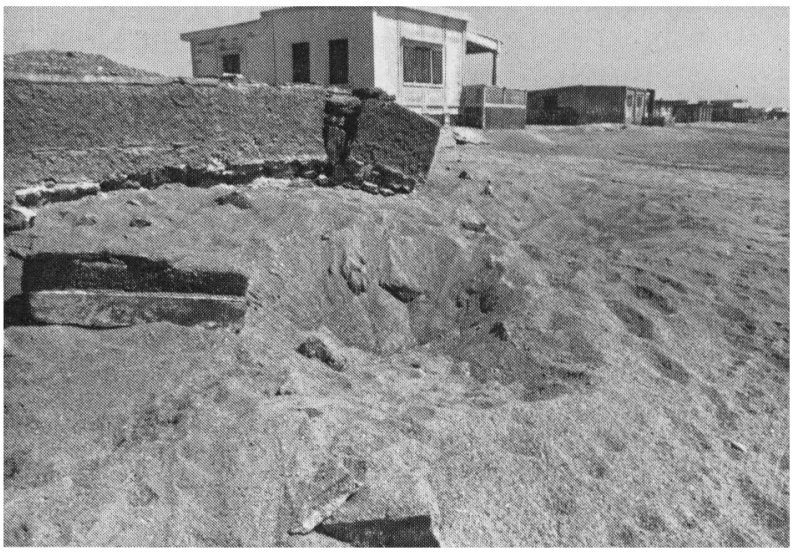

FIG. 2. Beach cottages and construction rubble restrict and reduce the quality of turtle nesting habitat at Sandspit and Hawkes Bay, near Karachi, Pakistan. Photo: Rodney V. Salm.

protection of the Green Turtle in Seychelles, Expert opinion has been requested, too, by Pakistan. The turtle protection laws stand secure for the moment in Pakistan, but nesting habitat is threatened and a turtle resources management plan is urgently required. Funding organizations should respond promptly to requests for aid and cultivate those countries that show active interest. Response to crises may prove too late.

\section{References}

Holloway, Colin W. (Ed.) (1969). Marine turtles: Proceedings of the working meeting of marine turtle specialists organized by IUCN at Morges, Switzerland, 10-13 March 1969. IUCN Publications New Series, Supplementary Paper No. 20, [iv +] 100 pp., illustr.

JACKSON, Peter F. R. (1976). Seychelles asked to continue marine turtle protection. Environmental Conservation, 3(2), p. 138.

RODNEY V. SALM

The Johns Hopkins University Department of Pathobiology 615 North Wolfe Street Baltimore

Maryland 21205, U.S.A.

\title{
Fire-ants Pose Threat to Galápagos Conservation
}

Little Fire-ants (Wasmannia auropunctata) are posing grave new threats to conservation in the Galápagos Islands, where Charles Darwin found living evidence for some of his beliefs concerning evolution. The Islands lie in the Pacific Ocean rather far off the coast of Ecuador, to which they belong. The Fire-ants were evidently introduced from the South American mainland to inhabitated areas of the Galápagos, but have now been discovered in some uninhabitated areas which are important conservationally.

Drastic steps are being taken to eliminate the Fire-ants before they spread further and damage invertebrate faunasuch as snails-which are important elements in the Galápagos ecosystems, with their Giant Tortoises, Land and Sea Iguanas, and other unique life-forms. Thus over an area of 250 square metres around the infected site on northeastern Santa Fé Island, all vegetation has been removed and burned, and the entire zone--including spaces under stones-has been treated with insecticides. Dr Craig MacFarland, Director of the Charles Darwin Research
Station, reports that these measures appear to have eliminated the Little Fire-ants, but surveillance is being continued.

Ironically it appears likely that scientists and National Park Personnel were themselves responsible for the infestation, which they probably introduced with fresh fruits and vegetables for their camp. To guard against this in future, carrying into the field of certain fruits, vegetables, and fresh foods, has been banned, while other foods and all camping gear is being disinfected. Tourists have been prohibited from taking any food ashore. Ecuadorian students are carrying out ecological-distributional studies of the Fire-ants and of native ant species, which it is hoped will assist in control if further measures are needed.

PETER F. R. JACKSON, Director of Information
World Wildlife Fund
1110 Morges
Switzerland.
World Wildlife Fund Switzerland. 